\title{
G6PD deficiency in Latin America: systematic review on prevalence and variants
}

\author{
Wuelton M Monteiro' ${ }^{1,2} /{ }^{+}$, Fernando FA Val ${ }^{1,2}$, André M Siqueira ${ }^{1,2}$, Gabriel P Franca ${ }^{1}$, \\ Vanderson S Sampaio', ${ }^{1,2}$, Gisely C Melo ${ }^{1,2}$, Anne CG Almeida ${ }^{1,2}$, Marcelo AM Brito ${ }^{1,2}$, \\ Henry M Peixoto ${ }^{3}$, Douglas Fuller ${ }^{4}$, Quique Bassat ${ }^{5}$, Gustavo AS Romero ${ }^{3,6}$, \\ Maria Regina F Oliveira ${ }^{3,6}$, Marcus Vinícius G Lacerda ${ }^{1,2}$
}

\begin{abstract}
${ }^{1}$ Gerência de Malária, Fundação de Medicina Tropical Dr Heitor Vieira Dourado, Manaus, AM, Brasil ${ }^{2}$ Escola Superior de Ciências da

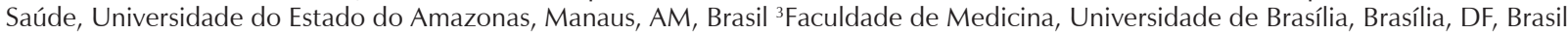
${ }^{4}$ Department of Geography and Regional Studies, University of Miami, Coral Gables, FL, USA ${ }^{5}$ Barcelona Centre for International Health Research, Hospital Clinic, University of Barcelona, Barcelona, Spain ${ }^{6}$ Instituto Nacional de Ciência e Tecnologia para Avaliação de Tecnologias em Saúde, Porto Alegre, RS, Brasil
\end{abstract}

Plasmodium vivax radical cure requires the use of primaquine (PQ), a drug that induces haemolysis in glucose6-phosphate dehydrogenase deficient (G6PDd) individuals, which further hampers malaria control efforts. The aim of this work was to study the G6PDd prevalence and variants in Latin America (LA) and the Caribbean region. A systematic search of the published literature was undertaken in August 2013. Bibliographies of manuscripts were also searched and additional references were identified. Low prevalence rates of G6PDd were documented in Argentina, Bolivia, Mexico, Peru and Uruguay, but studies from Curaçao, Ecuador, Jamaica, Saint Lucia, Suriname and Trinidad, as well as some surveys carried out in areas of Brazil, Colombia and Cuba, have shown a high prevalence (> $10 \%$ ) of G6PDd. The G6PD A- ${ }^{2022}$ mutation was the variant most broadly distributed across $L A$ and was identified in 81.1\% of the deficient individuals surveyed. G6PDd is a frequent phenomenon in LA, although certain Amerindian populations may not be affected, suggesting that $P Q$ could be safely used in these specific populations. Populationwide use of $P Q$ as part of malaria elimination strategies in LA cannot be supported unless a rapid, accurate and field-deployable G6PDd diagnostic test is made available.

Key words: G6PD deficiency - malaria control - Plasmodium vivax - primaquine - haemolysis - Amerindians

Glucose-6-phosphate dehydrogenase (G6PD) is a cytoplasmic enzyme. The major function of G6PD is the prevention of oxidative damage to cells by promoting detoxification of free radicals. This metabolic pathway involves the production of nicotinamide adenine dinucleotide phosphate (NADPH), which participates in the glutathione (GSH) cycle, protecting the cell against hydrogen peroxide-induced damage and assuring an oxidative balance profile within the cell (Cappellini \& Fiorelli 2008). The G6PD gene presents an X-linked pattern (Beutler 1994), where hemizygous males and homozygous females are deficient and heterozygous females may or may not be deficient because of mosaicism. Despite the majority of G6PD deficient (G6PDd) individuals being asymptomatic, some present haemolytic incidents that may be triggered by intrinsic or extrinsic

doi: 10.1590/0074-0276140123

Financial support: CNPq, PRONEX Malaria (575788/2008-9),

FAPEAM (HEMOVIVAX) (1027/2011 and 3140/2012)

GASR received a visiting fellowship from the FAPEAM (PECTI-

SAÚDE), QB has a fellowship from the program Miguel Servet of the ISCIII (CP11/00269), MVGL has a Level 1 fellowship from the CNPq.

+ Corresponding author: wueltonmm@ibest.com.br

Received 9 April 2014

Accepted 2 July 2014 stressors, e.g., diabetic ketoacidosis, drugs, pathogens or types of food, causing syndromes such as acute haemolytic anaemia (AHA), neonatal jaundice (NNJ) and congenital non-spherocytic haemolytic anaemia, with the resulting manifestations depending on the amount of oxidative stress experienced in the cells and the levels of enzyme activity (Mason et al. 2007).

G6PDd is found worldwide with varying frequencies depending on the region and ethnic group. The overall G6PDd allele frequency across malaria endemic countries is estimated to be $8 \%$, corresponding to approximately 220 million males and 133 million females (Howes et al. 2012). Variable enzyme activity levels have been measured among deficient individuals based on the diversity of mutations. The World Health Organization (WHO) has classifies G6PDd according to enzyme activity, ranging from $\leq 1 \%$ to over $150 \%$, classes I-V, respectively, in which classes I, II and III are considered at risk for haemolytic events (WHO 1989). The highest G6PDd prevalence has been found to occur in sub-Saharan Africa and the Arabian Peninsula (Howes et al. 2012). Recent data found 186 known G6PD genotypic variants, most of them resulting in phenotypes that are asymptomatic until exposed to haemolytic triggers (Minucci et al. 2012). These G6PD variants are heterogeneously spread among different countries, presenting distinct region-specific distributions (Howes et al. 2013), which could be related to specific routes of human migration. Among all the known deficiencies, the G6PD A- and the 
G6PD Mediterranean variants have been reported to be detected more frequently in certain populations and are the variants primarily responsible for the occurrence of haemolytic events (Frank 2005). The G6PD A- variant is the most predominant allele in the African continent, whereas the G6PD Mediterranean allele is more frequent in Western Asia (Howes et al. 2013).

Malaria in humans is predominantly caused by two Plasmodia species, Plasmodium falciparum and Plasmodium vivax and is estimated to be spread over more than 90 countries, putting nearly 3.3 billion people at risk of disease (Guerra et al. 2010, WHO 2012a). The prevalence of G6PDd across countries was found to have a good correlation with those where, historically, malaria transmission has occurred (Howes et al. 2012). The explanation for this association has been that G6PDd is associated with protection against $P$. falciparum (Mockenhaupt et al. 2003, Clark et al. 2009) and $P$. vivax infections (Leslie et al. 2010, Santana et al. 2013). The mechanism conferring resistance in G6PDd subjects may be related to an impaired antioxidant defence in ring-stage parasitised red cells, which could lead to membrane damage, triggering increased removal of infected cells by phagocytosis before parasite maturation to the trophozoite and schizont stages (Ruwende et al. 1995). G6PDd is also thought to be a protection factor against severe manifestations of malaria, although studies regarding which individuals, hemizygous males or heterozygous females, may be protected present discrepancies (Ruwende et al. 1995, Guindo et al. 2007).

In a context where the international community has committed to a renewed malaria eradication agenda (malERA 2011), many countries have been planning to reduce transmission or eliminate malaria, making the development and deployment of cost-effective strategies extremely necessary (Das \& Horton 2010). Primaquine (PQ), an 8-aminoquinoline, is currently the only Food and Drug Administration approved drug recommended to treat hepatic stages of the $P$. vivax. The WHO recommends that PQ should be used in radical cure for $P$. vivax malaria $(0.5 \mathrm{mg} / \mathrm{kg} / \mathrm{d}$ for 14 days) (WHO 2010) or as a gametocytocidal agent in uncomplicated $P$. falciparum infections $(0.25 \mathrm{mg} / \mathrm{kg}$ in a single dose) (WHO 2012b). The use of PQ or other 8-aminoquinolines such as tafenoquine (undergoing Phase III clinical trials) in G6PDd individuals presents serious risks, as these compounds may induce life-threatening haemolytic events, the intensities of which depends on the individual's enzyme activity profile (Llanos-Cuentas et al. 2013, von Seidlein et al. 2013). The WHO recommends that in mild-to-moderate G6PDd, PQ $(0.75 \mathrm{mg}$ base $/ \mathrm{kg})$ should be given once a week over eight weeks, while in severe G6PDd patients, PQ is contraindicated (WHO 2010).

Geographically, $P$. vivax is more widely distributed than $P$. falciparum, with the former species having a potential to cause morbidity and mortality amongst the 2.85 billion people living at risk of infection, most of them in Central and Southeast Asia and Latin America (LA) (Guerra et al. 2010). In LA and the Caribbean, only Chile, Uruguay, Cuba, Bahamas, Jamaica and other small countries in the Caribbean are now considered malaria-free, while Mexico, Haiti, Costa Rica, El Salvador, Panama,
Argentina and Paraguay have been classified as malariaeliminating countries. The remaining countries are still in the phase of controlling transmission (WHO 2012a). Predominance of $P$. vivax malaria in these countries is especially relevant given that radical cure requires the use of PQ, implying a risk of haemolysis and its adverse consequences in G6PDd individuals (Beutler \& Duparc 2007). The public health consequences of this condition deserve special attention because of the impossibility of using PQ in regions where there is a high prevalence of this deficiency, further hampering transmission control efforts for this parasite species (White 2008, Baird \& Surjadjaja 2011). Despite the clinical and epidemiological significance of the interaction between G6PDd and malaria, the prevalence of G6PDd and the extent of its clinical consequences have not been properly measured in LA populations.

In Brazil and other LA countries facing malaria as a public health problem, the treatment recommendation for $P$. vivax includes a full-course of $\mathrm{PQ}$ with no routine G6PDd screening. This short-sighted policy leads to the prescription of potentially haemolytic drugs, putting G6PDd individuals at risk of serious complications (Lacerda et al. 2012b, Monteiro et al. 2014). We therefore reviewed the existing literature to estimate the prevalence of G6PDd in LA and to identify the most frequent variants that affect this population, highlighting areas where more research is necessary in the region.

\section{MATERIALS AND METHODS}

A systematic review was performed to analyse the available published data on G6PDd prevalence, phenotypes and mutations in LA and the Caribbean. A broad free text search was made using a previously published search strategy (Monteiro et al. 2014). Potentially relevant papers in all languages were accessed from MEDLINE and LILACS for a review of the full texts. Additional articles were obtained through citation tracking of reviews/ opinion articles and original papers. To identify relevant papers, two independent reviewers examined titles, abstracts and full texts of the retrieved studies. Existing databases (Arends 1966, Fonseca et al. 2005, Howes et al. 2012 , 2013) were reviewed for any additional sources.

For G6PDd prevalence analysis, results of phenotyping tests from surveys in males were used. Potentially biased samples, including malaria patients, ethnically selected samples, individuals with a previous history of haemolytic anaemia, new-borns presenting jaundice and surveys based only on the search of specific genotypes were excluded because they tend to underestimate the real G6PDd prevalence (Howes et al. 2012). LA or Caribbean population migrants living in other continents were also excluded. Only surveys with precise information of the study location were included. Data on location of the study (country and locality), number of people tested, sex, number of G6PDd subjects, ethnicity, G6PD phenotypes/mutations found, relative prevalence of each variant and authorship information were extracted directly from the full length articles to structured Tables and Figures containing all the descriptive variables.

For G6PDd variant analysis, two types of studies were included: (i) representative community surveys on 
G6PDd prevalence assessed by gel electrophoresis and/or genotyping methods and (ii) non-representative surveys, including all types of studies and populations. Thus, to build a G6PDd database of the variant diversity in LA and the Caribbean, both types of papers were included. Classification of the variants was made according to a review published previously (Minucci et al. 2012) and according to information given by the original articles.

A map was created with the software ArcMap 10.1 in ArcGIS 10.1 (ESRI, USA) using estimates of the crude average prevalence for males. Separate male analysis and estimates for the map values were performed because phenotypic expression is more reliable, thus rendering male estimates more suitable for cross-locality comparisons (Howes et al. 2012). Spatial interpolation of G6PD prevalence was mapped using 70 representative community surveys corresponding to 103 study sites where males had been sampled. Duplicate studies performed at the same locations were excluded and the study with the bigger sample size was retained. Several different interpolation methods were tried, including ordinary kriging, Kernel Interpolation with Barriers and Inverse Distance Weighting (IDW). The latter was selected as it produces a contour surface that best represents broad zones where different G6PDd values may be predicted. IDW is a technique that determines cell values using a linearly weighted combination of a set of sample points. The weight is a function of inverse distance and the method assumes that the variable being mapped decreases in influence with distance from its sampled location (ArcMap 10.1 documentation). For this analysis, the output cell size was set to 0.33 , a power value of 2 was used, the search neighbourhood was set to smooth circular with a 30.15 radius and a smoothing factor of 0.2 was used. The sample size was used as a weight variable. No features were used as barriers.

\section{RESULTS AND DISCUSSION}

The MEDLINE search generated 487 papers and the LILACS search generated 140 papers. After assessing the inclusion criteria, 70 original papers with representative community surveys on G6PDd prevalence in males from $18 \mathrm{LA}$ and Caribbean countries were found (Supplementary data). This systematic review also revealed 24 publications regarding G6PDd prevalence among Amerindian populations (16 publications from the original search and 8 from after reading these primary references).

Moreover, 71 appropriate original papers regarding G6PD variant characterisation were retrieved. Thirtytwo additional articles were obtained through citation tracking of reviews/opinion articles and original papers. Of these 103 articles, 41 reported data from representative community surveys with G6PDd typing in males (28 using gel electrophoresis phenotyping and 13 using genotyping methods) (Supplementary data).

Prevalence estimates of G6PDd in LA and Caribbean - Overall numbers of individuals sampled were 63,716 males and 12,868 females (Table I). Considering only malaria endemic countries, 53,399 males and 10,079 females were tested. Brazil was the country with the largest number of males tested $(n=28,671 ; 53.7 \%$ of the male population tested in malaria endemic coun- tries), followed by Mexico ( $\mathrm{n}=13,126 ; 24.6 \%)$. Low prevalence rates were recorded from Argentina, Bolivia, Mexico, Peru and Uruguay. Studies performed in Curaçao, Ecuador, Jamaica, Saint Lucia, Suriname and Trinidad, as well as some surveys carried out in areas of Brazil, Colombia and Cuba, have shown a high prevalence (> 10\%) of G6PDd. Studies were unevenly distributed, with some malaria endemic countries, including Belize, Guatemala, Nicaragua, Panama, Guyana, French Guiana and Paraguay, not contributing any data.

Mapping showed large swathes in LA and Caribbean countries where G6PDd was predicted to have prevalence $\leq 2 \%$, namely in Mexico, Guatemala, Peru, Bolivia, Uruguay, Chile and Argentina (Fig. 1). Relative to these countries, prevalence was higher in the Caribbean islands, French Guiana, Suriname, Guyana, northwestern Venezuela and Pacific coastal regions of Colombia and Ecuador, where the majority of the estimated areas of prevalence above $10 \%$ were located. In the Amazon Region, prevalence estimates ranged from $4 \%$ in the southern areas to $10 \%$ in the Guiana borders. Prevalence in the northern Amazonian area is most likely overestimated due to the high G6PDd prevalence in Guyana and Suriname in the mapping model.

This map presents estimates of sub-national variations of G6PDd prevalence across LA and Caribbean countries. Recently, a global map presenting data at subnational levels using the same inclusion and exclusion criteria for retrieving articles was published (Howes et al. 2012). These authors mapped LA and Caribbean G6PDd based on 34 published articles. In the current review, by searching in LA specific databases and not applying any language restrictions, we were able to increase the number of usable publications to 70 articles. This higher sensitivity (great number of literature published regionally retrieved from LILACS database) most likely adds

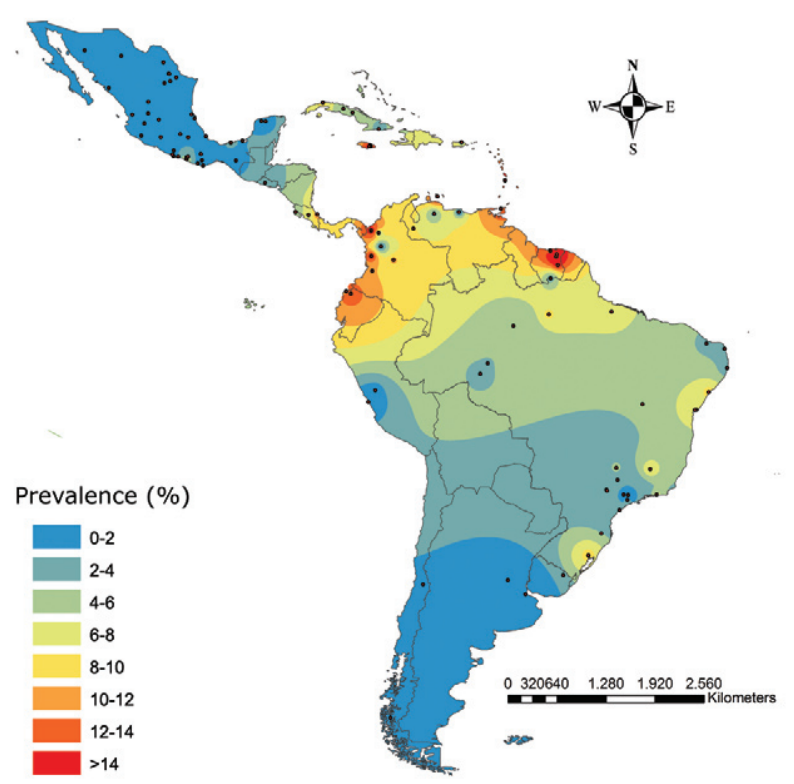

Fig. 1: map of estimated prevalence of glucose-6-phosphate dehydrogenase deficient across Latin America and the Caribbean countries. 
TABLE I

Summary of the results of surveys on glucose-6-phosphate dehydrogenase deficient prevalence in Latin America and the Caribbean

\begin{tabular}{|c|c|c|c|c|c|c|}
\hline Country & $\begin{array}{l}\text { Male } \\
\text { (n) }\end{array}$ & $\begin{array}{c}\text { Prevalence range } \\
\text { among studies } \\
(\%)\end{array}$ & $\begin{array}{c}\text { Female } \\
\text { (n) }\end{array}$ & $\begin{array}{c}\text { Prevalence range } \\
\text { among studies } \\
(\%)\end{array}$ & $\begin{array}{l}\text { Population not } \\
\text { discriminated by } \operatorname{sex}^{a} \\
\text { (n) }\end{array}$ & $\begin{array}{c}\text { Prevalence range } \\
\text { among studies } \\
(\%)\end{array}$ \\
\hline Argentina & 4,437 & $0.3-0.5$ & - & - & 4,642 & 1.1 \\
\hline Bolivia & 335 & $0.7-1.5$ & 200 & 0 & - & - \\
\hline Brazil & 28,671 & $0-12.9$ & 6,709 & $0-13.6$ & 9,801 & $1.1-13.3$ \\
\hline Colombia & 988 & $1.4-15.4$ & - & - & 611 & $3.1-12.7$ \\
\hline Costa Rica & 1,371 & $0.4-12.6$ & 1,683 & $0-7.8$ & 1,628 & $0.4-5.4$ \\
\hline Cuba & 7,957 & $0.6-16.1$ & 1,813 & $0.7-10.2$ & 500 & 3.6 \\
\hline Curaçao & 573 & 14 & 213 & 10.3 & - & - \\
\hline El Salvador & 778 & 2.4 & 416 & 6 & 370 & 0.5 \\
\hline Ecuador & 1,173 & $9.3-12.8$ & - & - & - & - \\
\hline Jamaica & 976 & $13.5-22.6$ & 524 & $4.1-28.3$ & - & - \\
\hline Mexico & 13,126 & $0-12.7$ & 488 & $0-0.9$ & 2,464 & $0-0.6$ \\
\hline Peru & 640 & $0-0.7$ & - & - & - & - \\
\hline Puerto Rico & 56 & 5.4 & 143 & 2.8 & - & - \\
\hline Saint Lucia & 427 & 14.8 & - & - & - & - \\
\hline Suriname & 1,507 & $3.2-20.2$ & 422 & 1.4 & - & - \\
\hline Trinidad & 328 & 13.4 & - & - & - & - \\
\hline Uruguay & - & - & 96 & 0 & 144 & 2.1 \\
\hline Venezuela & 373 & $0-3.5$ & 161 & $1.8-2.9$ & 112 & 0 \\
\hline Total & 63,716 & $0-22.6$ & 12,868 & $0-28.3$ & 20,272 & $0-13.3$ \\
\hline
\end{tabular}

$a$ : from studies conducted with male and female individuals without gender-specific prevalence.

more accuracy in the spatial distribution of G6PDd in this continent. The geographic patterns presented here corroborate the findings of a previous study by Howes et al. (2012), which showed lower G6PDd frequencies in Mexico, Argentina, Bolivia and Peru. However, a higher G6PDd prevalence was found in the Caribbean islands, Guianas, Pacific coastal regions of Colombia and Ecuador and part of the Brazilian Atlantic Coast compared to the previous study. These regions coincide with the areas that received the greatest contribution of African immigrants, particularly as part of the slave trade (Franco 1979).

G6PDd variants in LA and Caribbean - LA studies concerning the characterisation of the G6PDd were mostly conducted using gel electrophoresis and mainly carried out before 1990. As shown in Fig. 2A, the results from biochemical characterisations performed after representative community surveys on G6PDd prevalence revealed a broad geographic range of the African variant, which was recorded in 28 studies carried out in nine countries. Among 10,385 males tested in these studies, 518 G6PDd individuals were identified and further typed as carriers of the African (463 males; 89.4\%), Mediterranean (41 males in 5 countries; $7.9 \%$ ) or Seattle (1 male from Brazil; 0.2\%) variants. Samples from 13 individuals were not conclusively characterised by gel electrophoresis. In addition to G6PDd variant characterisation using samples from community surveys, 35 additional biochemical variants were recorded and published as case reports (see database presented in Table II). These publications are generally descriptions of putative new G6PD variants in people presenting non-spherocytic anaemia or episodes of haemolysis.

Fig. 2B presents the results from characterisation of G6PD variants at the DNA level performed after 13 community surveys on G6PDd prevalence from five countries. It showed that the G6PD encoded by the $G 6 P D A^{202 A}$ mutation is the most broadly distributed across LA and was identified in $81.1 \%$ of deficient individuals surveyed in the continent (687 of 847 total G6PDd males surveyed). Other variants identified included G6PD $A-^{968 G}$ (59 males; 7\%), G6PD Mediterranean (19; $2.2 \%)$, Santamaria $(16 ; 1.9 \%)$, Seattle $(16 ; 1.9 \%)$, Belém $(3 ; 0.3 \%)$ and Chatham $(2 ; 0.2 \%)$. Some other rare variants were recorded from Belém, in the Eastern Brazilian Amazon (Hamel et al. 2002). Thirty-four individuals were not typed because some investigations do not perform total G6PD gene sequencing, thus indicating that new mutations possibly exist in this continent. In Campinas, Brazil, nine out of the 74 deficient individuals were found to carry the G6PD A-202A mutation (12.2\%) (Saad et al. 1995). A community screening survey showed an estimated prevalence of $6 \%$ for the G6PD A-202A in Acrelândia, Brazil (Cardoso et al. 2012). 
A

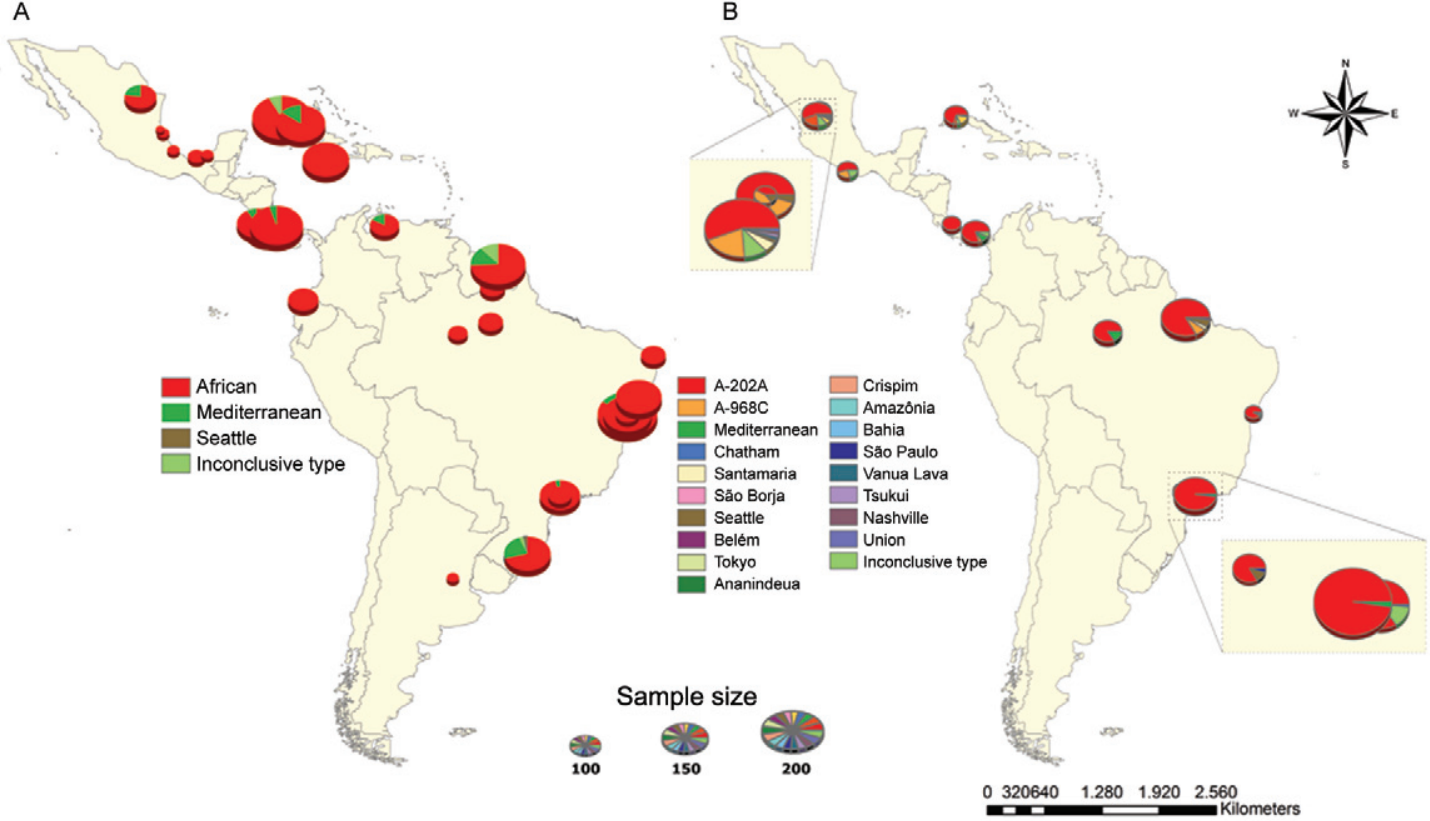

Fig. 2: spatial distribution of glucose-6-phosphate dehydrogenase deficient variants characterised by gel electrophoresis (A) and molecular analysis (B) in Latin American and Caribbean community-level studies. Sample size is reflected in the size of the pie charts.

TABLE II

Glucose-6-phosphate dehydrogenase phenotypes found in Latin America and the Caribbean

\begin{tabular}{|c|c|c|c|c|}
\hline Name & Class & Country & References & $\begin{array}{c}\text { Frequency } \\
(\%)\end{array}$ \\
\hline \multirow[t]{9}{*}{ A- } & III & Brazil & $\begin{array}{l}\text { Saldanha et al. (1969), Azevedo and Azevedo (1974), Azevêdo et al. } \\
\text { (1980, 1981), Weimer et al. (1981, 1991, 1998), Franco et al. (1982), } \\
\text { Conceição et al. (1987), Santos et al. (1987), Schneider et al. (1987), } \\
\text { Garlipp and Ramalho (1988), Saad and Costa (1992), Bortolini et al. } \\
\text { (1997), Silva et al. (2004), Santana et al. (2009), Iglessias (2009) }\end{array}$ & 89.4 \\
\hline & & Costa Rica & Sáenz et al. $(1985,1986)$, Chaves et al. (1988), Madrigal et al. (1990) & \\
\hline & & Cuba & González et al. (1975), Hidalgo et al. (1987) & \\
\hline & & Ecuador & Martínez-Labarga et al. (1999) & \\
\hline & & Jamaica & Gibbs et al. (1972) & \\
\hline & & Mexico & Lisker et al. (1966, 1969, 1981, 1988, 1990) & \\
\hline & & Suriname & Geerdink et al. (1974) & \\
\hline & & Venezuela & Boada and Yates (1979), Bortolini et al. (1998) & \\
\hline & & Uruguay & Weimer et al. (1998) & \\
\hline Attica & III & Puerto Rico & McCurdy et al. (1973) & Rare \\
\hline Aymara & None & Chile & Ferrell et al. (1980) & Rare \\
\hline Carapicuíba & II/III & Brazil & Barretto and Nonoyama (1991) & Rare \\
\hline Castilla & III & Mexico & Lisker et al. (1977) & \\
\hline Caujerí & III & Cuba & Gutiérrez et al. (1987) & Rare \\
\hline $\begin{array}{l}\text { Chiapas } \\
\text { Chicago }\end{array}$ & $\begin{array}{l}\text { II } \\
\text { II }\end{array}$ & $\begin{array}{c}\text { Mexico } \\
\text { Puerto Rico }\end{array}$ & $\begin{array}{l}\text { Lisker et al. (1978) } \\
\text { McCurdy et al. (1973) }\end{array}$ & Rare \\
\hline Cuiabá & IV & Brazil & Barretto and Nonoyama (1987) & Rare \\
\hline Distrito Federal & III & Mexico & Lisker et al. (1981) & \\
\hline
\end{tabular}




\begin{tabular}{|c|c|c|c|c|}
\hline Name & Class & Country & References & $\begin{array}{c}\text { Frequency } \\
(\%)\end{array}$ \\
\hline El Morro & III & Puerto Rico & McCurdy et al. (1973) & Rare \\
\hline Farroupilha & II/III & Brazil & Weimer et al. (1998) & Rare \\
\hline Guadalajara & I & Mexico & Vaca et al. (1982) & Rare \\
\hline Guantánamo & III & Cuba & Gutiérrez et al. (1987) & Rare \\
\hline Guaíba & IV & Brazil & Weimer et al. $(1981,1998)$ & Rare \\
\hline Jalisco & III & Mexico & Vaca et al. (1985) & Rare \\
\hline Lages & III & Brazil & Weimer et al. (1998) & Rare \\
\hline Laguna & III & Brazil & Weimer et al. $(1984,1998)$ & Rare \\
\hline La Habana & III & Cuba & González et al. (1980) & Rare \\
\hline \multirow[t]{5}{*}{ Mediterranean } & II & Brazil & $\begin{array}{l}\text { Azevedo and Azevedo (1974), Azevêdo et al. (1980), Weimer et al. } \\
\text { (1981, 1998), Franco et al. (1982), González-González and Calcines } \\
\text { (1986), Garlipp and Ramalho (1988), Santana et al. (2009) }\end{array}$ & 7.9 \\
\hline & & Costa Rica & Sáenz et al. (1985, 1986), Chaves et al. (1988), Madrigal et al. (1990) & \\
\hline & & Cuba & González-González and Calcines (1986), Hidalgo et al. (1987) & \\
\hline & & Mexico & Lisker et al. (1976) & \\
\hline & & Venezuela & Boada and Yates (1979) & \\
\hline Mexico City & IV & Mexico & Lisker et al. (1972) & Rare \\
\hline Minas Gerais & IV & Brazil & Azevedo and Yoshida (1969), Hutz et al. (1977), Weimer et al. $(1981,1998)$ & Rare \\
\hline Morelia & IV & Mexico & Vaca et al. (1985) & Rare \\
\hline Nashville Anaheim & I & Brazil & Weimer et al. (1998) & Rare \\
\hline Porto Alegre & IV & Brazil & Hutz et al. (1977), Weimer et al. $(1981,1998)$ & Rare \\
\hline Puerto Limón & I & Costa Rica & Elizondo et al. (1982) & Rare \\
\hline Puerto Rico & III & Puerto Rico & McCurdy et al. (1973) & Rare \\
\hline San José & III & Costa Rica & Castro and Snyder (1974) & Rare \\
\hline San Juan & III & Puerto Rico & McCurdy et al. (1973) & Rare \\
\hline Santa Clara & III & Cuba & Gonzalez et al. (1990) & Rare \\
\hline Santamaría & II & Costa Rica & Sáenz et al. (1984) & Rare \\
\hline São Borja & IV & Brazil & Weimer et al. (1998) & Rare \\
\hline São Paulo & IV & Brazil & Barretto (1983) & Rare \\
\hline Seattle/Athens-like & III & Brazil & McCurdy et al. (1973), Hutz et al. (1977), Weimer et al. (1981, 1998) & 0.2 \\
\hline Tepic & III & Mexico & Lisker et al. (1985) & \\
\hline Trinacria & III & Mexico & Vaca et al. (1985) & Rare \\
\hline Varadero & I & Cuba & Estrada et al. (1982) & Rare \\
\hline Villa Clara & III & Cuba & Gonzalez et al. (1990) & Rare \\
\hline
\end{tabular}

Tepic, Castilla, Distrito Federal phenotypes were identified as A- $(202 \mathrm{G} \rightarrow \mathrm{A}, 376 \mathrm{~A} \rightarrow \mathrm{G})$ a posteriori according to genetic characterisation (Beutler et al. 1991a). Frequency was retrieved from representative community surveys in males. A rare variant has a prevalence of less than $0.1 \%$.

This systematic review led to the creation of a database of G6PD mutations found in LA and the Caribbean (Table III). Thirty works from seven countries presented data on the enzyme characterisation of G6PD variants at the DNA level. To date, 38 G6PDd mutations have been reported in LA: among these, 30 (78.9\%) are single nucleotide substitutions, seven (18.4\%) are multiple mutations ( 2 or more substitutions) and one (2.6\%) is a dele- tion. Eleven variants were identified in class I G6PDd and 27 were classified in classes II or III G6PDd. Twenty-three novel mutations were described in LA.

G6PD characterisation at the DNA level was performed with samples collected from 13 community surveys on G6PDd prevalence from only five countries. This scarcity of data constitutes a major limitation for a more reliable understanding of G6PDd epidemiology 


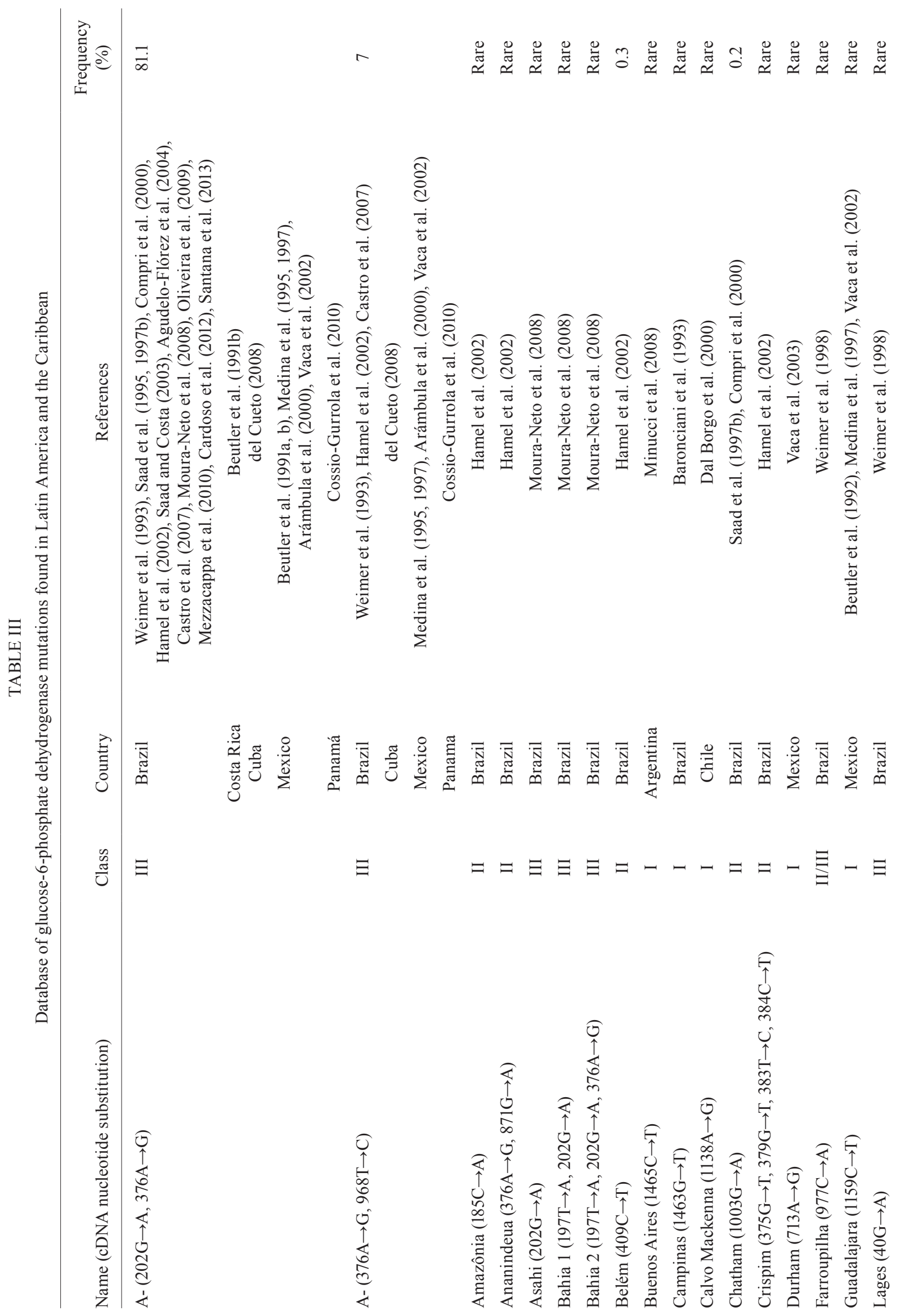




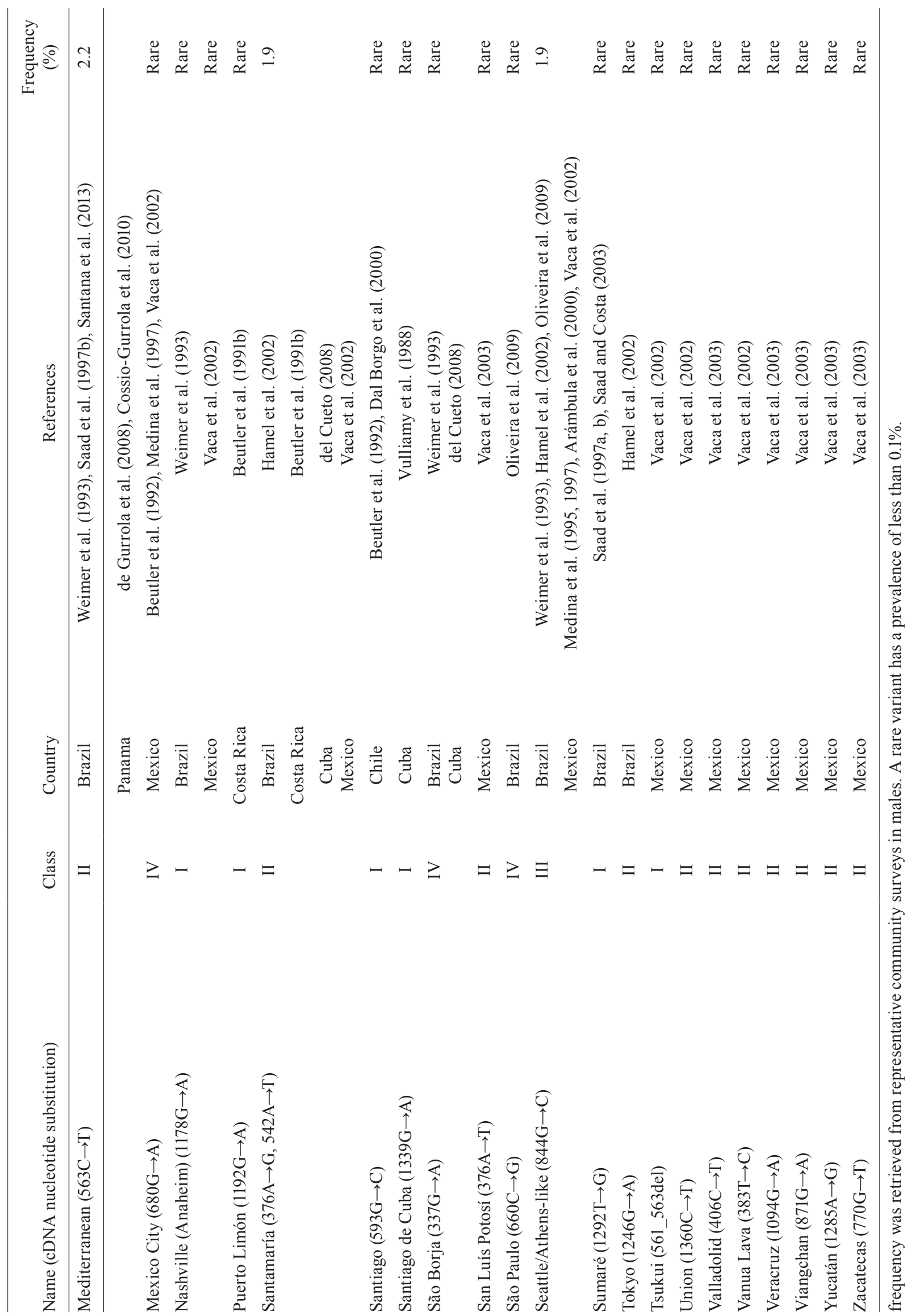


in LA. Biochemical methods strongly suggested the predominance of the African variant across this continent, in agreement with other genotyping studies from the same areas, suggesting the reasonable reliability of gel electrophoresis as a diagnostic tool for G6PD enzyme variants.

Investigation of different PQ regimens must also include appropriate measures of tolerability and be able to quantify the risk of severe adverse events, especially in patients with deficient variants of G6PD. However, only a few publications have addressed the correlation between G6PD variants and clinical presentations in LA. Out of the 30 articles reporting G6PDd at the DNA level (Table III), 11 referred to reports of rare class I mutations associated with chronic non-spherocytic haemolytic anaemia. Anaemia was recorded in a case report focusing on one male G6PD A-202A mutation carrier (Agudelo-Flórez et al. 2004). Mild haemolysis was observed in a girl with both G6PD Sumaré (class I variant) and G6PD A- alleles (Saad \& Costa 2003). One Brazilian publication presents three male asymptomatic carriers of the Mediterranean, São Borja and Seattle mutations and one carrier of the Anaheim mutation with a history of NNJ, several hospitalisation episodes and severe anaemia (Weimer et al. 1993). None of these mentioned case reports involved treatment with PQ.

The severity of particular G6PD mutations and their prevalence in a population determine the risk of individual (and eventually population-wide) administration of PQ. For example, G6PDd is common among people of African origin, but the enzyme deficiency is relatively mild (A- variant) with most having greater than $10 \%$ of the wild-type enzyme activity (Beutler 1991). Patients with the G6PD A- variant are relatively resistant to serious reactions to $\mathrm{PQ}$-induced haemolysis (Dern et al. 1954); G6PD A- individuals dosed with daily PQ for four months have been observed to typically recover from relatively shallow AHA within about three weeks, despite continued daily dosing (Dern et al. 1954, Alving et al. 1960). Some reports from LA countries are in agreement with these findings. In this continent, G6PD A- is the predominant variant observed among hundreds of healthy male blood donors (Saad et al. 1997b, Compri et al. 2000, Hamel et al. 2002, Oliveira et al. 2009). Moreover, this variant was not a risk factor for moderate hyperbilirubinaemia (Mezzacappa et al. 2010) or anaemia (Cardoso et al. 2012) in Brazil. On the other hand, G6PD A- type deficiency was associated with significant haemoglobin drop in patients using antimalarial preparations containing dapsone in Africa (Pamba et al. 2012).

Nonetheless, these findings do not conclusively indicate that non-specific administration of PQ is safe. To be acceptable, mass drug administration (MDA) needs to heavily rely on the safety of the intervention, as it will reach a majority of healthy individuals (Hsiang et al. 2013, Kondrashin et al. 2014). The use of an unsafe drug for MDA purposes could impose serious hazards to the population, as there is no efficient or accurate rapid diagnostic test currently available. The relatively low number of reported cases of haemolysis from malaria endemic countries that prescribe PQ irrespective of G6PD status assessment may be due to under-diagnosis and underreporting of this complication, rendering the need for a more thorough assessment of the clinical burden of this condition in the region (Douglas et al. 2012). Should MDA be conducted with PQ in countries with a high prevalence of underlying G6PD deficiency, a high number of adverse events would be expected to occur at the community level, in accordance with the distribution of G6PD variants present in this community. Albeit sporadic, the number of cases of severe haemolysis, haemoglobinuria, acute kidney injury and associated fatalities may not be significant, but they are not negligible. This is especially true in certain geographical areas in which G6PDd rates are high, particularly in those nations where the Mediterranean variant is prevalent. The G6PD Mediterranean variant prevails in certain ethnic groups originating in the Mediterranean and West Asia. Individuals with the G6PD Mediterranean variant have minimal G6PD activity $(<1 \%)$ and are predisposed to favism and severe life threatening haemolysis following PQ therapy (Beutler 1991, Howes et al. 2013). In Panama, a mutation analysis revealed that a Mediterranean variant was behind the development of kernicterus after exposure to naphthalene in a male patient (de Gurrola et al. 2008). In Manaus, Brazil, G6PDd was associated with a considerably higher risk of malaria-related transfusions, suggesting that G6PDd may contribute to a considerable proportion of malaria-related complications in an area with an unexpectedly high prevalence of the Mediterranean variant (Ramos-Júnior et al. 2010, Lacerda et al. 2012a, Santana et al. 2013).

A recent systematic review analysed 47 cases of confirmed PQ-induced haemolysis in LA and the Caribbean (Monteiro et al. 2014). Unfortunately, none of these cases had genotyped for G6PD variants.

G6PDd among Amerindian populations - This systematic review analysed 24 publications regarding G6PDd prevalence among Amerindians belonging to 55 ethnic groups living in 12 countries and 64 different villages. A total of 7,205 individuals were tested for G6PDd (2,482 males, 499 females and 4,224 individuals without gender information). Most of this information was generated from anthropological studies on the genetic variability of indigenous groups using the G6PD phenotype as one of the markers. A great interest in this area has allowed the accumulation of valuable information regarding G6PDd prevalence in this ethnic group.

In LA, the first work concerning G6PDd in areas of P. vivax circulation found no G6PDd individuals amongst 228 Peruvian Amerindians (Best 1959). Indeed, studies from different areas of this continent confirmed the virtual absence or a very low frequency of G6PDd in Amerindian populations. In this review, only eight deficient individuals were detected among 7,205 screened Amerindians. In Colombia, one Wanauna individual was found to be deficient (Monsalve et al. 1987) and in Mexico, four Amerindians were diagnosed as G6PDd (Lisker et al. 1966). Authors of the last two studies concluded that this could be explained by the introduction of genes from black neighbouring communities. In the Amazon, G6PDd was detected in one Makiritare Amerindian with approximately $20 \%$ of normal G6PD enzyme activity in relation to average G6PD activity found in control individuals 
from the same village (Mohrenweiser \& Neel 1984). The geographic patterns presented here reinforce these findings, with lower G6PDd frequencies observed in Mexico, Argentina, Bolivia and Peru and this finding may be explained by the fact that large portions of the populations in these countries have an Amerindian background.

In parallel with the virtual absence of G6PDd among Amerindian populations, the literature indicates that these groups of people are not susceptible to haemolysis caused by oxidative stressors such as PQ and other drugs. A recent systematic review has shown that among all published cases of haemolysis triggered by various oxidative agents in LA, none have involved Amerindians (Monteiro et al. 2014). Reinforcing these results, in Nicaragua, the administration of 10-20 mg of PQ base during 14 days to 321 Miskito Amerindians with chronic malaria did not lead to any report of secondary haemolysis (Thaeler Jr et al. 1953). This probable safety upon $\mathrm{PQ}$ administration in Amerindian population is of great value to malaria control programmes because malaria remains a major health problem in Amerindian villages across this continent.

Safety of $P Q$ use in LA and the Caribbean - The most feared complication of PQ administration is triggering haemolysis in G6PDd individuals. PQ may also cause clinically non-significant haemolysis in non-G6PDd individuals as well. Other major side effects include methemoglobinaemia (MetHb), hypersensitivity reactions and gastrointestinal disturbances (Hill et al. 2006). Because G6PDd screening prior to PQ administration is not usually routine practice in LA or Caribbean countries, the risk of drug-induced haemolytic episodes is always present. Although PQ is the only available drug presenting good efficacy for the treatment of both $P$. vivax and $P$. falciparum primary infections and relapses of $P$. vivax malaria (Baird 2011), it still presents many uncertainties regarding its mode of function, safety and tolerability (Steinhardt et al. 2011) despite having been extensively used for more than 60 years. Safety issues are most concerning in those populations considered most vulnerable, including pregnant women and very young children with uncertain G6PD status, for which the WHO recommends not using PQ due to scarce evidence of its safety (WHO 2010).

Several reports describe haemolytic events associated with PQ use in G6PDd individuals in LA and the Caribbean, including El-Salvador (Bloch et al. 1970), Cuba (Pérez \& Meléndez 1989, Menéndez-Capote et al. 1997), Trinidad and Tobago (Chadee et al. 1996), Puerto Rico (McCurdy et al. 1973) and Brazil (Silva et al. 2004, Ramos-Júnior et al. 2010, Lacerda et al. 2012a). A large portion of these patients required blood replacement therapy, presented long-lasting haemolysis and were unable to complete full treatment (Monteiro et al. 2014).

The clinical impact of G6PDd is also important in the Brazilian Amazon, a region accounting for $99.8 \%$ of the registered cases of malaria in Brazil (Oliveira-Ferreira et al. 2010). In this region, G6PDd has been associated with an increased risk for malaria-related transfusions (Santana et al. 2009, 2013) and death triggered by PQ-induced haemolysis (Lacerda et al. 2012a). Of note, the standard PQ regimen in Brazil differs from that recommended by the WHO. In an attempt to increase treatment compliance, the Brazilian Ministry of Health, in the mid-1990s, recommended the administration of $30 \mathrm{mg}$ /day of PQ over only seven days (Marques et al. 2001), rather than maintaining the conventional $15 \mathrm{mg} /$ day, 14-day regimen course proposed by the WHO. The decrease in length of PQ treatment to seven days led to an increase in the drug dosage (Silva et al. 2010). The precise consequences of this schedule change on the risk of haemolysis prevalence triggered by PQ in G6PDd individuals remain to be determined.

Other adverse events, such as MetHb, may also occur following PQ therapy. In G6PDd patients, a significantly higher occurrence of MetHb was observed following oral therapy with PQ when compared to non-G6PDd individuals (Santana et al. 2007, Ferreira et al. 2011). In Nicaragua, however, administration of 10-20 mg of PQ base daily over 14 days to 321 Miskito Indians with chronic malaria did not lead to any case of secondary adverse events (Thaeler Jr et al. 1953). LA literature is contradictory in the presentation of adverse events after treatment with PQ. Despite one Colombian study reporting that two and five-fold higher PQ dosages caused only shortterm mild-to-moderate side effects (Carmona-Fonseca et al. 2009), another study from this same country reported severe gastrointestinal distress in a small proportion of non-immune male soldiers (Soto et al. 1999).

Most of the countries presenting cases of PQ-induced haemolysis present a higher prevalence of G6PDd when compared to other countries. Although only a few cases are reported in these studies, the real prevalence of clinical haemolytic syndromes is unknown, most likely due to lack of appropriate surveillance. As most studies aim to study the efficacy of PQ regimens against malaria, safety issues are still systematically underexplored. Gaps still need to be filled regarding the presence of serious adverse events due to PQ therapy in both normal G6PD and deficient populations.

Some perspectives concerning rapid diagnostic tests in $L A$ - Several technical and operational knowledge gaps must be addressed to expand access to G6PDd testing and to ensure that a patient's G6PD status is known before deciding to administer PQ (Domingo et al. 2013). A rapid and accurate diagnosis of G6PDd under field conditions before starting PQ treatment is currently a major challenge (malERA 2011, Domingo et al. 2013). A prerequisite to introducing G6PD testing is the availability of high-quality G6PDd tests with product profiles that are compatible with end-use cases. The diagnostic gold standard technique for detecting G6PDd is based on the measurement of NADPH production by the enzyme by means of spectrophotometry, thus requiring a laboratory environment, sophisticated equipment and experienced personnel. For screening activities in less complex environments, the fluorescent spot test has been considered the most appropriate assay, although it requires ultraviolet lamp, bath and micropipette. Given the characteristics described above, none of the currently available G6PDd tests can be routinely employed in field conditions across most malarial areas. 
In this context, in 2012, decision-makers gathered at a workshop held in Bangkok, Thailand and indicated that a rapid test for G6PDd should have characteristics similar to rapid tests used in malaria diagnosis: feasibility and ease of interpretation, stability at high temperature and humidity, ability to test on capillary blood, sensitivity and specificity higher than $95 \%$ and $75 \%$, respectively, with a cut-off set at $30-40 \%$ of the median normal G6PD activity (Domingo et al. 2013).

Although G6PDd systematic testing is currently not performed in malaria endemic areas, there are two rapid tests to detect G6PDd in field conditions: BinaxNOW ${ }^{\circledR}$ $\mathrm{G} 6 \mathrm{PD}$, which is already being commercialised, and CareStart $^{\mathbb{B}}$ G6PD, which was recently developed and is now showing promising results (Tinley et al. 2010, Kim et al. 2011, von Fricken et al. 2014). The scarcity of studies on both tests may limit their use by malaria control and eradication programs because there are issues related to their physical and biochemical conservation in the field. High levels of humidity and temperature impact the tests' accuracies by indirectly impairing the establishment of deficiency cut-off points. Better assessments are required to better determine the real usefulness and costs of these tests in LA and Caribbean countries. BinaxNOW ${ }^{\circledR}$ G6PD must be kept between $15-30^{\circ} \mathrm{C}$ for storage and between $18-25^{\circ} \mathrm{C}$ during performance and this test requires venous blood for the essay, which may increase operating costs and hamper its use. In the United States of America, this test presented high accuracy with $98 \%$ sensitivity and $97 \%$ specificity, when using a cut-off of $<4.0 \mathrm{U} / \mathrm{gHb}$, corresponding to $49 \%$ of normal G6PD activity in the sample (Tinley et al. 2010). Regarding CareStart ${ }^{\mathbb{B}}$ G6PD, a study from Cambodia established sensitivity and specificity of $68 \%$ and $100 \%$, respectively, at a cut-off of $<3.6 \mathrm{U} / \mathrm{gHb}$ (30\% of normal activity), demonstrating that the test is not affected by high storage or execution temperatures when performed with samples collected by venipuncture or finger-stick on peripheral blood puncture (Kim et al. 2011).

A standard approach that could define absolute values of normal G6PD activity may be required to validate G6PDd diagnostic tests (Domingo et al. 2013). Typically, G6PDd has been defined as a percentage of normal G6PD activity. No rapid test for G6PD has been assessed in LA malaria endemic epidemiological conditions. In this review of LA and Caribbean studies, a lack of standardisation was noticed in the attempts both to assess normal G6PD activity as well as to define a cut-off for G6PDd diagnosis. Twenty-five community surveys estimated G6PDd prevalence by quantitative methods but, unfortunately, the majority of the studies used inconsistent definitions of normal G6PD activity though different G6PD cut-off points or degrees of G6PDd. Some studies followed manufacturer's definitions of normal activity and G6PDd. Ambiguity in the method of calculation presents practical difficulties in deploying G6PD tests in routine care in LA and Caribbean countries. This ambiguity in interpreting results is particularly problematic in qualitative tests, which highlights that an accurate evaluation of rapid tests is urgently needed in these countries.
From a public health perspective, uncertainty remains in whether G6PD testing deficiency status needs to be taken into account for PQ-based radical cure in some populations, as reflected in the current WHO guidelines. However, from a patient management perspective, where the individual risk/benefit ratio dictates optimal treatment, knowing the G6PD status of the patient is a prerequisite for prescribing an 8-aminoquinoline-based drug (Domingo et al. 2013). Given the scarcity of rapid test evaluations, it becomes a priority to study the use these tests in the diagnosis of G6PD deficiency in tropical areas where malaria is endemic, especially regarding their accuracy. These data are as essential for economic evaluation as for their incorporation by health services. After extensive studies of accuracy, the cost-effectiveness and budget impact of incorporating G6PDd diagnosis in the standard of care for malaria will need to be assessed to support decision-making steps.

A cost-effectiveness analysis is currently the method most commonly used for economic evaluation in health care and in the field of health technology assessment. Such an approach systematically compares costs and consequences of health interventions for prevention, diagnosis or treatment from among the options that have a common purpose (Haddix et al. 2003). The evidence about the cost-effectiveness of interventions is generally used to instruct decisions regarding the allocation of funds from the public sector, helping to identify interventions that represent the best use of resources. In addition to cost-effectiveness analyses, the evaluation of the budget impact can aid decision making by providing financial forecasts if the technology in question is adopted by national health systems (Ribeiro et al. 2012).

Rapid tests have the potential to change radically the healthcare process for patients presenting G6PDd, potentially also allowing the optimisation of available financial resources because deficiency diagnosis likely decreases other costs such as those related to hospitalisations. It is necessary, however, to compare such costs and benefits to those related to possible relapses from $P$. vivax infections and thus determine the importance of G6PDd detection among individuals infected with $P$. vivax through an effective and economically viable rapid test. It is also important to consider a local research agenda in LA to regionally assess the cost and accuracy of rapid tests in field conditions. If rapid tests prove effective in field conditions, studies of cost-effectiveness and budget impact for health services are recommended to support the incorporation of these tests into control programs aimed at malaria elimination in the Western Hemisphere.

Concluding remarks - Malaria elimination will be possible only with serious regional and international efforts addressing asymptomatic infection and persistent $P$. vivax infection. Currently available drugs that can radically cure $P$. vivax malaria and are able to reduce transmission of malaria parasites are those in the 8 -aminoquinoline family, such as PQ. Tafenoquine, which is also an 8 -aminoquinoline, is currently being assessed as a single-dose radical cure therapy and may represent a significant advance in $P$. vivax therapy. Un- 
fortunately, individuals carrying the G6PDd trait are at risk to develop severe haemolysis if exposed to any of these drugs, implying that radical cure regimens will require broader testing for G6PD deficiency.

In conclusion, (i) low prevalence rates of G6PDd were recorded in Argentina, Bolivia, Mexico, Peru and Uruguay. Studies performed in Curaçao, Ecuador, Jamaica, Saint Lucia, Suriname and Trinidad, as well as some surveys carried out in areas of Brazil, Colombia and Cuba showed high prevalence rates $(>10 \%)$ of G6PDd, (ii) G6PD encoded by the G6PD $A^{202 A}$ mutation is the most broadly distributed genotype across LA, identified in $81.1 \%$ of deficient individuals surveyed in the continent, (iii) G6PDd seems to be virtually absent among Amerindians, suggesting that PQ use is safe in these populations and (iv) rapid and accurate diagnosis of G6PDd under field conditions remains a major challenge in LA. The development of a rapid G6PD diagnostic test could help in reducing unnecessary exposure to drugs capable of inducing haemolysis, such as PQ, because LA faces a scarcity of clinical and epidemiological information concerning this enzyme's activity in the population. The development of newer and inexpensive methods for field-testing of G6PD deficiency should go hand in hand with studies of PQ and tafenoquine effectiveness. Reliable exclusion of patients at risk of severe harm opens the possibility for safer and more effective deployment of high dose regimens. If the elimination of $P$. vivax is to be achieved, a coordinated effort will be necessary to provide evidence across the spectrum of $P$. vivax endemic regions and to deploy a safe anti-relapse therapy regimen in an effective manner.

\section{ACKNOWLEDGEMENTS}

For all people that contributed with references, and to the reviewer, for contributing to the improvement of the manuscript.

\section{REFERENCES}

Agudelo-Flórez P, Costa-Carvalho BT, López JA, Redher J, Newburger PE, Olalla-Saad ST, Condino-Neto A 2004. Association of glucose-6-phosphate dehydrogenase deficiency and X-linked chronic granulomatous disease in a child with anemia and recurrent infections. Am J Hematol 75: 151-156.

Alving AS, Johnson CF, Tarlov AR, Brewer GJ, Kellermeyer RW, Carson PE 1960. Mitigation of the haemolytic effect of primaquine and enhancement of its action against exoerythrocytic forms of the Chesson strain of Plasmodium vivax by intermittent regimens of drug administration: a preliminary report. Bull World Health Organ 22: 621-631.

Arámbula E, Aguilar LJC, Vaca G 2000. Glucose-6-phosphate dehydrogenase mutations and haplotypes in Mexican Mestizos. Blood Cells Mol Dis 26: 387-394.

Arends T 1966. Haemoglobinopathies, thalassemia and glucose-6phosphate deficiency in Latin America and the West Indies. $N Z$ Med J 65: 831-844.

Azevêdo ES, Alves AF, da Silva MC, Souza MG, Lima AMMD, Azevedo WC 1980. Distribution of abnormal hemoglobins and glucose-6-phosphate dehydrogenase variants in 1,200 school children of Bahia, Brazil. Am J Phys Anthropol 53: 509-512.

Azevedo ES, Azevedo TFS 1974. Glucose-6-phosphate dehydrogenase deficiency and neonatal jaundice in Bahia, Brazil. Cienc Cult 26: 44-47.
Azevêdo ES, Silva KM, da Silva MC, Lima AM, Fortuna CM, Santos MG 1981. Genetic and anthropological studies in the island of Itaparica, Bahia, Brazil. Hum Hered 31: 353-357.

Azevedo ES, Yoshida A 1969. Brazilian variant of glucose 6-phosphate dehydrogenase (Gd Minas Gerais). Nature 222: 380-382.

Baird JK 2011. Radical cure: the case for anti-relapse therapy against all malarias. Clin Infect Dis 52: 621-623.

Baird JK, Surjadjaja C 2011. Consideration of ethics in primaquine therapy against malaria transmission. Trends Parasitol 27: 11-16.

Baronciani L, Tricta F, Beutler E 1993. G6PD "Campinas": a deficient enzyme with a mutation at the far 3' end of the gene. Hum Mutat 2: $77-78$.

Barretto OC 1983. New variant of erythrocyte glucose-6-phosphate dehydrogenase: Gd São Paulo. Rev Hosp Clin Fac Med Sao Paulo 38: 247-248.

Barretto OC, Nonoyama K 1987. Gd(+) Cuiabá, a new rare glucose6-phosphate dehydrogenase variant presenting normal activity. Hum Genet 77: 201-202.

Barretto OC, Nonoyama K 1991. Gd(-) Carapicuiba, a rare glucose-6phosphate dehydrogenase variant associated with moderate enzyme deficiency and chronic hemolysis. Braz J Med Biol Res 24: 133-139.

Best WR 1959. Absence of erythrocyte glucose-6-phosphate dehydrogenase deficiency in certain Peruvian Indians. J Lab Clin Med 54: 791.

Beutler E 1991. Glucose-6-phosphate dehydrogenase deficiency. $N$ Engl J Med 324: 169-174.

Beutler E 1994. G6PD deficiency. Blood 84: 3613-3636.

Beutler E, Duparc S 2007. Glucose-6-phosphate dehydrogenase deficiency and antimalarial drug development. Am J Trop Med Hyg 77: 779-789.

Beutler E, Kuhl W, Ramirez E, Lisker R 1991a. Some Mexican glucose-6-phosphate dehydrogenase variants revisited. Hum Genet 86: 371-374.

Beutler E, Kuhl W, Sáenz GF, Rodríguez W 1991b. Mutation analysis of glucose-6-phosphate dehydrogenase (G6PD) variants in Costa Rica. Hum Genet 87: 462-464.

Beutler E, Westwood B, Prchal JT, Vaca G, Bartsocas CS, Baronciani L 1992. New glucose-6-phosphate dehydrogenase mutations from various ethnic groups. Blood 80: 255-256.

Bloch M, Sancho G, Rivera H 1970. Characteristics of GPD deficiency in El Salvador. Sangre (Barc) 15: 163-169.

Boada JJ, Yates AP 1979. Phenotypes of glucose-6 phosphate dehydrogenase in a Mestizo population. Acta Cient Venez 30: 172-174.

Bortolini MC, da Silva-Júnior WA, Weimer TA, Zago MA, de Guerra DC, Schneider MP, Layrisse Z, Castellano HM, Salzano FM 1998. Protein and hypervariable tandem repeat diversity in eight African-derived South American populations: inferred relationships do not coincide. Hum Biol 70: 443-461.

Bortolini MC, Weimer TA, Salzano FM, Moura LB, Silva MCBO 1997. Genetic structure of two Afro-Brazilian populations. Int $J$ Anthropol 12: 5-16.

Cappellini MD, Fiorelli G 2008. Glucose-6-phosphate dehydrogenase deficiency. Lancet 371: 64-74.

Cardoso MA, Scopel KKG, Muniz PT, Villamor E, Ferreira MU 2012. Underlying factors associated with anemia in Amazonian children: a population-based, cross-sectional study. PLoS ONE 7: e36341.

Carmona-Fonseca J, Alvarez G, Maestre A 2009. Methemoglobinemia and adverse events in Plasmodium vivax malaria patients 
associated with high doses of primaquine treatment. Am J Trop Med Hyg 80: 188-193.

Castro GA, Snyder LM 1974. G6PD San José: a new variant characterized by NADPH inhibition studies. Humangenetik 21: 361-363.

Castro SM, Weber R, Matte U, Giugliani R 2007. Molecular characterization of glucose-6-phosphate dehydrogenase deficiency in patients from the southern Brazilian city of Porto Alegre, RS. Genet Mol Biol 30: 10-13.

Chadee DD, Tilluckdharry CC, Doon R 1996. Imported cerebral malaria complicated with glucose-6-phosphate dehydrogenase deficiency. West Indian Med J 45: 97-99.

Chaves M, Sáenz GF, Quintana E, Montero A, Jiménez J 1988. Polymorphism of erythrocytic glucose-6-phosphate dehydrogenase in Costa Rica. Sangre (Barc) 33: 12-14.

Clark TG, Fry AE, Auburn S, Campino S, Diakite M, Green A, Richardson A, Teo YY, Small K, Wilson J, Jallow M, Sisay-Joof F, Pinder M, Sabeti P, Kwiatkowski DP, Rockett KA 2009. Allelic heterogeneity of G6PD deficiency in West Africa and severe malaria susceptibility. Eur J Hum Genet 17: 1080-1085.

Compri MB, Saad ST, Ramalho AS 2000. Genetico-epidemiological and molecular investigation of G-6-PD deficiency in a Brazilian community. Cad Saude Publica 16: 335-342.

Conceição MM, Salzano FM, Franco MHLP, Weimer TA, Krieger H 1987. Demography, genetics and race admixture in Aracaju, Brazil. Rev Bras Genet 10: 313-331.

Cossio-Gurrola G, Arámbula-Meraz E, Perea M, García N, Correa AS, Rueda K, Chial M 2010. Glucose-6-phosphate dehydrogenase (G6PD) molecular variant deficiency: identification in Panama pediatric population. Blood Cells Mol Dis 44: 115-116.

Dal Borgo PA, Rosario SC, Cavieres AM 2000. Dos nuevas mutaciones de glucose-6-fosfato deshidrogenasa, G6PD Santiago y G6PD Calvo Mackenna. Rev Chil Pediatr 71: 419-422.

Das P, Horton R 2010. Malaria elimination: worthy, challenging and just possible. Lancet 376: 1515-1517.

de Gurrola GC, Araúz JJ, Durán E, Aguilar-Medina M, Ramos-Payán R, García-Magallanes N, Pacheco GV, Meraz EA 2008. Kernicterus by glucose-6-phosphate dehydrogenase deficiency: a case report and review of the literature. J Med Case Rep 2: 146.

del Cueto ME 2008. Caracterización molecular de variantes de glucosa-6-fostato deshidrogenasa (G6PD) en la población cubana. Rev Cubana Hematol Inmunol Hemoter 24: 1-9.

Dern RJ, BeutlerE, Alving AS 1954. The hemolytic effect of primaquine. II. The natural course of the hemolytic anemia and the mechanism of its self-limited character. $J$ Lab Clin Med 44: 171-176.

Domingo GJ, Satyagraha AW, Anvikar A, Baird K, Bancone G, Bansil P, Carter N, Cheng Q, Culpepper J, Eziefula C, Fukuda M, Green J, Hwang J, Lacerda M, McGray S, Menard D, Nosten F, Nuchprayoon I, Oo NN, Bualombai P, Pumpradit W, Qian K, Recht J, Roca A, Satimai W, Sovannaroth S, Vestergaard L, von Seidlein L 2013. G6PD testing in support of treatment and elimination of malaria: recommendations for evaluation of G6PD tests. Malar J 12: 391.

Douglas NM, John GK, Seidlein L, Anstey NM, Price RN 2012. Chemotherapeutic strategies for reducing transmission of Plasmodium vivax malaria. Adv Parasitol 80: 271-300.

Elizondo J, Sáenz GF, Páez CA, Ramón M, García M, Gutiérrez A, Estrada M 1982. G6PD-Puerto Limón: a new deficient variant of glucose-6-phosphate dehydrogenase associated with congenital non-spherocytic hemolytic anemia. Hum Genet 62: 110-112.

Estrada M, García M, Gutiérrez A, Quintero I, González R 1982. G6PD Varadero. A new variant of glucose-6-phosphate dehy- drogenase associated with congenital non-spherocytic hemolytic anemia. Vox Sang 43: 102-104.

Ferreira MES, Gomes MSM, Vieira JLF 2011. Methemoglobinemia in patients with Plasmodium vivax receiving oral therapy with primaquine. Rev Soc Bras Med Trop 44: 113-115.

Ferrell RE, Bertin T, Barton SA, Rothhammer F, Schull WJ 1980. The multinational Andean genetic and health program. IX. Gene frequencies and rare variants of 20 serum proteins and erythrocyte enzymes in the Aymara of Chile. Am J Hum Genet 32: 92-102.

Fonseca D, Mateus H, Silva C, Contreras N, Restrepo C 2005. Deficiencia de glucosa-6-fosfato deshidrogenasa: aspectos generales de la eritroenzimopatía más frecuente en el mundo. Acta Med Colomb 30: 59-64.

Franco JL 1979. The slave trade in the Caribean and Latin America from the fifteenth to the nineteenth century. In United Nations Educational, Scientific and Cultural Organization (ed.), The African slave trade from the fifteenth to the nineteenth century, Imprimeries Réunies de Chambéry, Paris, p. 88-100.

Franco MH, Weimer TA, Salzano FM 1982. Blood polymorphisms and racial admixture in two Brazilian populations. Am J Phys Anthropol 58: 127-132.

Frank JE 2005. Diagnosis and management of G6PD deficiency. Am Fam Physician 72: 1277-1282.

Garlipp CR, Ramalho AS 1988. Aspectos clínicos e laboratoriais da deficiência de desidrogenase de 6-fosfato de glicose (G-6-PD) em recém-nascidos brasileiros. Rev Bras Genet 11: 717-728.

Geerdink RA, Bartstra HA, van Veen JMS 1974. Serum proteins and red cell enzymes in Trio and Wajana Indians from Surinam. Am J Hum Genet 26: 581-587.

Gibbs WN, Ottey F, Dyer H 1972. Distribution of glucose-6-phosphate dehydrogenase phenotypes in Jamaica. Am J Hum Genet 24: 18-23.

Gonzalez OL, Espina AL, Calcines PH 1990. G6P-DH Santa Clara and G6P-DH Villa Clara: two new Cuban variants. Acta Paediatr Hung 30: 17-26.

González R, Estrada M, Colombo B 1975. G-6-PD polymorphism and racial admixture in the Cuban population. Humangenetik 26: 75-78.

González R, Estrada M, García M, Gutierrez A 1980. G6PD Ciudad de la Habana: a new slow variant with deficiency found in a $\mathrm{Cu}-$ ban family. Hum Genet 55: 133-135.

González-González O, Calcines P 1986. Alteraciones metabolicas eritrocitarias en recién nacidos a término con ictericia fisiologica: glutation reducido y glucosa-6-fosfato deshidrogenasa. Medicentro 2: 89-93.

Guerra CA, Howes RE, Patil AP, Gething PW, Van Boeckel TP, Temperley WH, Kabaria CW, Tatem AJ, Manh BH, Elyazar IRF, Baird JK, Snow RW, Hay SI 2010. The international limits and population at risk of Plasmodium vivax transmission in 2009. PLoS Negl Trop Dis 4: e774.

Guindo A, Fairhurst RM, Doumbo OK, Wellems TE, Diallo DA 2007. X-linked G6PD deficiency protects hemizygous males, but not heterozygous females against severe malaria. PLoS Med 4: e66.

Gutiérrez A, García M, Estrada M, Quintero I, González R 1987. Glucose-6-phosphate dehydrogenase (G6PD) Guantánamo and G6PD Caujerí: two new glucose-6-phosphate dehydrogenasedeficient variants found in Cuba. Biochem Genet 25: 231-238.

Haddix A, Teutsch SM, Corso PS 2003. Prevention effectiveness - a guide to decision analysis and economic evaluation, 2nd ed., Oxford University Press, Oxford, $264 \mathrm{pp}$.

Hamel AR, Cabral IR, Sales TSI, Costa FF, Saad STO 2002. Molecular heterogeneity of G6PD deficiency in an Amazonian population and description of four new variants. Blood Cells Mol Dis 28: 399-406. 
Hidalgo PC, González OL, Rodríguez M, Castellanos T 1987. Análisis del polimorfismo genético de la G-6-PD eritrocitaria en la región central de Cuba. Rev Medicentro Electrónica 3: 149-157

Hill DR, Baird JK, Parise ME, Lewis LS, Ryan ET, Magill AJ 2006. Primaquine: report from CDC expert meeting on malaria chemoprophylaxis I. Am J Trop Med Hyg 75: 402-415.

Howes RE, Dewi M, Piel FB, Monteiro WM, Battle KE, Messina JP, Sakuntabhai A, Satyagraha AW, Williams TN, Baird JK, Hay SI 2013. Spatial distribution of G6PD deficiency variants across malaria-endemic regions. Malar J 12: 418.

Howes RE, Piel FB, Patil AP, Nyangiri OA, Gething PW, Dewi M, Hogg MM, Battle KE, Padilla CD, Baird JK, Hay SI 2012. G6PD deficiency prevalence and estimates of affected populations in malaria endemic countries: a geostatistical model-based map. PLoS Med 9: e1001339.

Hsiang MS, Hwang J, Tao AR, Liu Y, Bennett A, Shanks GD, Cao J, Kachur SP, Feachem RGA, Gosling RD, Gao Q 2013. Mass drug administration for the control and elimination of Plasmodium vivax malaria: an ecological study from Jiangsu province, China. Malar J 12: 383

Hutz MH, Yoshida A, Salzano FM 1977. Three rare G6PD variants from Porto Alegre, Brazil. Hum Genet 39: 191-197.

Iglessias MAC 2009. Frequência da deficiência de glicose-6-fosfato desidrogenase (G-6-PD) e sua relação com a icterícia neonatal. Rev Bras Hematol Hemoter 31: 57.

Kim S, Nguon C, Guillard B, Duong S, Chy S, Sum S, Nhem S, Bouchier C, Tichit M, Christophel E, Taylor WRJ, Baird JK, Menard D 2011. Performance of the CareStartTM G6PD deficiency screening test, a point-of-care diagnostic for primaquine therapy screening. PLOS ONE 6: e28357.

Kondrashin A, Baranova AM, Ashley EA, Recht J, White NJ, Sergiev VP 2014. Mass primaquine treatment to eliminate vivax malaria: lessons from the past. Malar J 13: 51.

Lacerda MVG, Fragoso SCP, Alecrim MGC, Alexandre MAA, Magalhães BML, Siqueira AM, Ferreira LCL, Araújo JR, Mourão MPG, Ferrer M, Castillo P, Martin-Jaular L, FernandezBecerra C, Portillo H, Ordi J, Alonso PL, Bassat Q 2012a. Postmortem characterization of patients with clinical diagnosis of Plasmodium vivax malaria: to what extent does this parasite kill? Clin Infect Dis 55: 67-74.

Lacerda MVG, Mourão MPG, Alexandre MA, Siqueira AM, Magalhães BML, Martinez-Espinosa FE, Filho FSS, Brasil P, Ventura AMRS, Tada MS, Couto VSCD, Silva AR, Silva RSU, Alecrim MGC 2012b. Understanding the clinical spectrum of complicated Plasmodium vivax malaria: a systematic review on the contributions of the Brazilian literature. Malar J 11: 12.

Leslie T, Briceño M, Mayan I, Mohammed N, Klinkenberg E, Sibley CH, Whitty CJM, Rowland M 2010. The impact of phenotypic and genotypic G6PD deficiency on risk of Plasmodium vivax infection: a case-control study amongst Afghan refugees in Pakistan. PLoS Med 7: e1000283.

Lisker R, Briceno RP, Agrilar L, Yoshida A 1978. A variant glucose6-phosphate dehydrogenase $\mathrm{Gd}(-)$ Chiapas associated with moderate enzyme deficiency and occasional hemolytic anemia. Hum Genet 43: 81-84.

Lisker R, Briceño RP, Sosa R, Shein M 1976. Hereditary and epidemiological aspects of erythrocyte glucose-6-phosphate dehydrogenase deficiency in Mexico. Gac Med Mex 111: 454-458.

Lisker R, Briceno RP, Zavala C, Navarrette JI, Wessels M, Yoshida A 1977. A glucose 6-phosphate dehydrogenase Gd (-) Castilla variant characterized by mild deficiency associated with druginduced hemolytic anemia. $J$ Lab Clin Med 90: 754-759.
Lisker R, Córdova MS, Zárate QBG 1969. Studies on several genetic hematological traits of the Mexican population. XVI. Hemoglobin $\mathrm{S}$ and glucose-6-phosphate dehydrogenase deficiency in the east coast. Am J Phys Anthropol 30: 349-354.

Lisker R, Linares C, Motulsky AG 1972. Glucose-6-phosphate dehydrogenase Mexico. A new variant with enzyme deficiency, abnormal mobility and absence of hemolysis. J Lab Clin Med 79: 788-793.

Lisker R, Pérez-Briceño R, Beutler E 1985. A new glucose-6-phosphate dehydrogenase variant, Gd(-) Tepic, characterized by moderate enzyme deficiency and mild episodes of hemolytic anemia. Hum Genet 69: 19-21.

Lisker R, Pérez-Briceno R, Granados J, Babinsky V 1988. Gene frequencies and admixture estimates in the state of Puebla, Mexico. Am J Phys Anthropol 76: 331-335.

Lisker R, Pérez-Briceño R, Ravé V, Yoshida A 1981. Federal District glucose-6-phosphate dehydrogenase $\mathrm{Gd}(-)$ : a new variant associated with moderate enzyme deficiency and occasional hemolytic anemia. Rev Invest Clin 33: 209-211.

Lisker R, Ramirez E, Briceño RP, Granados J, Babinsky V 1990. Gene frequencies and admixture estimates in four Mexican urban centers. Hum Biol 62: 791-801.

Lisker R, Zarate G, Loria A 1966. Studies on several genetic hematologic traits of Mexicans IX. Abnormal hemoglobins and erythrocytic glucose-6-phosphate dehydrogenase deficiency in several Indian tribes. Blood 27: 824-830.

Llanos-Cuentas A, Lacerda MV, Rueangweerayut R, Krudsood S, Gupta SK, Kochar SK, Arthur P, Chuenchom N, Möhrle JJ, Duparc S, Ugwuegbulam C, Kleim J-P, Carter N, Green JA, Kellam L 2013. Tafenoquine plus chloroquine for the treatment and relapse prevention of Plasmodium vivax malaria (DETECTIVE): a multicentre, double-blind, randomised, Phase $2 \mathrm{~b}$ dose-selection study. Lancet 383: 1049-1058.

Madrigal L, Sáenz G, Chávez M 1990. Glucose-6-phosphate dehydrogenase deficiency: its frequency in $\mathrm{Hb} \mathrm{AS}$ and $\mathrm{Hb} \mathrm{AA}$ individuals among the black population of Limón. Sangre (Barc) 35: 413-414.

malERA - Consultative Group on Basic Science and Enabling Technologies 2011. A research agenda for malaria eradication: basic science and enabling technologies. PLoS Med 8: e1000399.

Marques AC, Valencia A, Silva AR, Silva CJM, Fontes CJF, Netto JCA, Souza JM, Boulos M, Alecrim MGC, Tada MS, Tauil PL, Macedo VO, Alecrim WD 2001. Manual de terapêutica da malária. Available from: bvsms.saude.gov.br/bvs/publicacoes/funasa/manu_terapeutica_malaria.pdf.

Martínez-Labarga C, Rickards O, Scacchi R, Corbo RM, Biondi G, Peña JA, de Vieira CV, Guevara AE, Santurino MS, de Stefano GF 1999. Genetic population structure of two African-Ecuadorian communities of Esmeraldas. Am J Phys Anthropol 109: 159-174.

Mason PJ, Bautista JM, Gilsanz F 2007. G6PD deficiency: the genotype-phenotype association. Blood Rev 21: 267-283.

McCurdy PR, Maldonado N, Dillon DE, Conrad ME 1973. Variants of glucose-6-phosphate dehydrogenase (G-6-PD) associated with G-6-PD deficiency in Puerto Ricans. J Lab Clin Med 82: 432-437.

Medina MD, Vaca G, Esparza A, Westwood B, Beutler E 1995. Molecular heterogeneity of G-6-PD deficiency in Mexico. Arch Med Res 26: 111-113.

Medina MD, Vaca G, Lopez-Guido B, Westwood B, Beutler E 1997. Molecular genetics of glucose-6-phosphate dehydrogenase deficiency in Mexico. Blood Cells Mol Dis 23: 88-94.

Menéndez-Capote R, Pérez LD, Suárez CL 1997. Hemolysis and primaquine treatment. Preliminary report. Rev Cub Med Trop 49: 136-138. 
Mezzacappa MA, Facchini FP, Pinto AC, Cassone AEL, Souza DS, Bezerra MAC, Albuquerque DM, Saad STO, Costa FF 2010. Clinical and genetic risk factors for moderate hyperbilirubinemia in Brazilian newborn infants. J Perinatol 30: 819-826.

Minucci A, Concolino P, Vendittelli F, Giardina B, Zuppi C, Capoluongo E 2008. Glucose-6-phosphate dehydrogenase Buenos Aires: a novel de novo missense mutation associated with severe enzyme deficiency. Clin Biochem 41: 742-745.

Minucci A, Moradkhani K, Hwang MJ, Zuppi C, Giardina B, Capoluongo E 2012. Glucose-6-phosphate dehydrogenase (G6PD) mutations database: review of the "old" and update of the new mutations. Blood Cells Mol Dis 48: 154-165.

Mockenhaupt FP, Mandelkow J, Till H, Ehrhardt S, Eggelte TA, Bienzle U 2003. Reduced prevalence of Plasmodium falciparum infection and of concomitant anaemia in pregnant women with heterozygous G6PD deficiency. Trop Med Int Health 8: 118-124.

Mohrenweiser H, Neel J 1984. A "disproportion" between the frequency of rare electromorphs and enzyme deficiency variants in Amerindians. Am J Hum Genet 36: 655-662.

Monsalve MV, Espinel A, de Restrepo HG, Calvo M, Suarez MC, Rodriguez A 1987. Frequency of five genetic polymorphisms in two populations of Colombia. Rev Bras Genet 10: 247-251.

Monteiro W, Franca G, Melo G, Queiroz A, Brito M, Peixoto H, Oliveira M, Romero G, Bassat Q, Lacerda M 2014. Clinical presentations of G6PD deficiency in Latin American and Caribbean populations: systematic review and implications for malaria elimination programmes. Malar J 13: 70.

Moura-Neto JP, Dourado MV, Reis MG, Gonçalves MS 2008. A novel c.197T -> A variant among Brazilian neonates with glucose-6phosphate dehydrogenase deficiency. Genet Mol Biol 31: 33-35.

Oliveira RAG, Oshiro M, Hirata MH, Hirata RDC, Ribeiro GS, Medeiros TMD, Barretto OCO 2009. A novel point mutation in a class IV glucose-6-phosphate dehydrogenase variant (G6PD São Paulo) and polymorphic G6PD variants in São Paulo state, Brazil. Genet Mol Biol 32: 251-254.

Oliveira-Ferreira J, Lacerda MV, Brasil P, Ladislau JL, Tauil PL, DanielRibeiro CT 2010. Malaria in Brazil: an overview. Malar J 9: 115.

Pamba A, Richardson ND, Carter N, Duparc S, Premji Z, Tiono AB, Luzzatto L 2012. Clinical spectrum and severity of hemolytic anemia in glucose 6-phosphate dehydrogenase-deficient children receiving dapsone. Blood 120: 4123-4133.

Pérez JLM, Meléndez PH 1989. Síndrome hemolítico por primaquina y deficiencia de glucosa-6-fosfato deshidrogenasa. Rev Cub Med Trop 41: 299-306.

Ramos-Júnior WM, Sardinha JFJ, Costa MRF, Santana MS, Alecrim MGC, Lacerda MVG 2010. Clinical aspects of hemolysis in patients with $P$. vivax malaria treated with primaquine in the Brazilian Amazon. Braz J Infect Dis 14: 410-412.

Ribeiro R, Cristina V, Santos C, Tavares F, Elias S 2012. Diretriz para análises de impacto orçamentário de tecnologias em saúde no Brasil. Cad Saude Publica 7: 1223-1238.

Ruwende C, Khoo SC, Snow RW, Yates SN, Kwiatkowski D, Gupta S, Warn P, Allsopp CE, Gilbert SC, Peschu N 1995. Natural selection of hemi and heterozygotes for G6PD deficiency in Africa by resistance to severe malaria. Nature 376: 246-249.

Saad ST, Costa FF 1992. Glucose-6-phosphate dehydrogenase deficiency and sickle cell disease in Brazil. Hum Hered 42: 125-128.

Saad ST, Costa FF 2003. Mild hemolysis in a girl with G6PD Sumaré (class I variant) associated with G6PD A-. Blood Cells Mol Dis 30: $238-240$.
Saad ST, Costa FF, Salles TS, Sonatti MF, Figueiredo MS 1995. Glucose-6-phosphate dehydrogenase deficiency in sickle cell disease by DNA analysis. Blood 85: 601-602.

Saad ST, Salles TS, Arruda VR, Sonati MF, Costa FF 1997a. G6PD Sumaré: a novel mutation in the G6PD gene (1292 T-->G) associated with chronic non-spherocytic anemia. Hum Mutat 10: 245-247.

Saad ST, Salles TS, Carvalho MH, Costa FF 1997b. Molecular characterization of glucose-6-phosphate dehydrogenase deficiency in Brazil. Hum Hered 47: 17-21.

Sáenz BR, Jiménez DM, Chaves VM, Quintana GEM, Sáenz RGF 1986. Coexistence of hemoglobin S and glucose-6-phosphate dehydrogenase deficiency in negroid population. Rev Costarric Cienc Med 7: 305-310.

Sáenz GF, Chaves M, Berrantes A, Elizondo J, Montero AG, Yoshida A 1984. A glucose-6-phosphate dehydrogenase variant, $\mathrm{Gd}(-)$ Santamaria found in Costa Rica. Acta Haematol 72: 37-40.

Sáenz GF, Chávez M, Briceño J, Quintana E, Arroyo G, Valenciano E, Porras AGM, Jiménez J 1985. Hemoglobin and erythrocyte G6PD polymorphism in preschool children in Santa Cruz, Guanacaste, Costa Rica. Rev Costarric Cienc Med 6: 126-130.

Saldanha PH, Nóbrega FG, Maia JC 1969. Distribution and heredity of erythrocyte G6PD activity and electrophoretic variants among different racial groups at São Paulo, Brazil. J Med Genet 6: 48-54.

Santana MS, Lacerda MVG, Barbosa MGV, Alecrim WD, Alecrim MGC 2009. Glucose-6-phosphate dehydrogenase deficiency in an endemic area for malaria in Manaus: a cross-sectional survey in the Brazilian Amazon. PLoS ONE 4: e5259.

Santana MS, Monteiro WM, Siqueira AM, Costa MF, Sampaio V, Lacerda MV, Alecrim MG 2013. Glucose-6-phosphate dehydrogenase deficient variants are associated with reduced susceptibility to malaria in the Brazilian Amazon. Trans $R$ Soc Trop Med Hyg 107: 301-306.

Santana MS, Rocha MAF, Arcanjo ARL, Sardinha JFJ, Alecrim WD, Alecrim MGC 2007. Association of methemoglobinemia and glucose-6-phosphate dehydrogenase deficiency in malaria patients treated with primaquine. Rev Soc Bras Med Trop 40: 533-536.

Santos SEB, Guerreiro JF, Salzano FM, Weimer TA, Hutz MH, Franco MHLP 1987. Mobility, blood genetic traits and race mixture in the Amazonian population of Oriximiná. Rev Bras Genet 10: 745-759.

Schneider H, Guerreiro JF, dos Santos SEB, Weimer TA, Schneider MPC, Salzano FM 1987. Isolate breakdown in Amazonia: the blacks of the Trombetas River. Rev Bras Genet 10: 565-574.

Silva AR, Espinosa FEM, Souza JM, Boulos M, Alecrim MGC, Pereira MPL, Tada MS, Mascheretti M, Lapouble OMM, Marchesini P, Montoya RA, Braz RM, Chaves T, Alecrim WD 2010. Guia prático de tratamento da malária no Brasil. Available from: bvsms.saude.gov.br/bvs/publicacoes/guia_pratico_malaria.pdf.

Silva MCM, Santos EB, Costal EG, Filho MGS, Guerreiro JF, Póvoa MM 2004. Clinical and laboratorial alterations in Plasmodium vivax malaria patients and glucose-6-phosphate dehydrogenase deficiency treated with primaquine at $0.50 \mathrm{mg} / \mathrm{kg} / \mathrm{day}$. Rev $S o c$ Bras Med Trop 37: 215-217.

Soto J, Toledo J, Rodriquez M, Sanchez J, Herrera R, Padilla J, Berman J 1999. Double-blind, randomized, placebo-controlled assessment of chloroquine/primaquine prophylaxis for malaria in non-immune Colombian soldiers. Clin Infect Dis 29: 199-201.

Steinhardt LC, Magill AJ, Arguin PM 2011. Review: malaria chemoprophylaxis for travelers to Latin America. Am J Trop Med Hyg 85: 1015-1024.

Thaeler Jr AD, Arnold J, Alving AS 1953. A clinical study of primaquine (S.N. 13,272) in the treatment of malaria among the Miskito Indians of Nicaragua. Am J Trop Med Hyg 2: 989-999. 
Tinley KE, Loughlin AM, Jepson A, Barnett ED 2010. Evaluation of a rapid qualitative enzyme chromatographic test for glucose-6-phosphate dehydrogenase deficiency. Am J Trop Med Hyg 82: 210-214.

Vaca G, Arámbula E, Esparza A 2002. Molecular heterogeneity of glucose-6-phosphate dehydrogenase deficiency in Mexico: overall results of a 7-year project. Blood Cells Mol Dis 28: 436-444.

Vaca G, Arámbula E, Monsalvo A, Medina C, Nuñez C, Sandoval L, López-Guido B 2003. Glucose-6-phosphate dehydrogenase (G-6-PD) mutations in Mexico: four new G-6-PD variants. Blood Cells Mol Dis 31: 112-120.

Vaca G, Ibarra B, Cruz DG, Medina C, Romero F, Cantú JM, Beutler E 1985. G-6-PD Jalisco and G-6-PD Morelia: two new Mexican variants. Hum Genet 71: 82-85.

Vaca G, Ibarra B, Romero F, Olivares N, Cantú JM, Beutler E 1982. G-6-PD Guadalajara. A new mutant associated with chronic nonspherocytic hemolytic anemia. Hum Genet 61: 175-176.

von Fricken ME, Weppelmann TA, Eaton WT, Masse R, Madsen VE, Rochars B, Okech BA 2014. Performance of the CareStart glucose-6-phosphate dehydrogenase (G6PD) rapid diagnostic test in Gressier, Haiti. Am J Trop Med Hyg 91: 77-80.

von Seidlein L, Auburn S, Espino F, Shanks D, Cheng Q, McCarthy J, Baird K, Moyes C, Howes R, Ménard D, Bancone G, WinastiSatyahraha A, Vestergaard LS, Green J, Domingo G, Yeung S, Price R 2013. Review of key knowledge gaps in glucose-6-phosphate dehydrogenase deficiency detection with regard to the safe clinical deployment of 8-aminoquinoline treatment regimens: a workshop report. Malar J 12: 112.

Vulliamy TJ, D’Urso M, Battistuzzi G, Estrada M, Foulkes NS, Martini G, Calabro V, Poggi V, Giordano R, Town M 1988. Diverse point mutations in the human glucose-6-phosphate dehydrogenase gene cause enzyme deficiency and mild or severe hemolytic anemia. Proc Natl Acad Sci USA 85: 5171-5175.
Weimer TA, Salzano FM, Hutz MH 1981. Erythrocyte isozymes and hemoglobin types in a southern Brazilian population. J Hum Evol 10: 319-328.

Weimer TA, Salzano FM, Westwood B, Beutler E 1993. Molecular characterization of glucose-6-phosphate dehydrogenase variants from Brazil. Hum Biol 65: 41-47.

Weimer TA, Salzano FM, Westwood B, Beutler E 1998. G6PD variants in three South American ethnic groups: population distribution and description of two new mutations. Hum Hered 48: 92-96.

Weimer TA, Schüler L, Beutler E, Salzano FM 1984. Gd (+) Laguna, a new rare glucose-6-phosphate dehydrogenase variant from Brazil. Hum Genet 65: 402-404.

Weimer TA, Tavares Neto J, Franco MHLP, Hutz MH, Salzano FM, Kubo RR, Rosa RTD, Friedrisch JR, Prata A 1991. Genetic aspects of Schistosoma mansoni infection severity. Rev Bras Genet 14: 623-630.

White NJ 2008. The role of anti-malarial drugs in eliminating malaria. Malar J 7: S8.

WHO - World Health Organization 1989. Glucose-6-phosphate dehydrogenase deficiency. WHO Working Group. Bull World Health Organ 67: 601-611.

WHO - World Health Organization 2010. Guidelines for the treatment of malaria. Available from: who.int/malaria/publications/ atoz/9789241547925/en/.

WHO - World Health Organization 2012a. World Malaria Report 2012. Available from: who.int/malaria/publications/world malaria_report_2012/en/.

WHO - World Health Organization 2012b. The safety and effectivenes of single dose primaquine as a P. falciparum gametocyte. Available from: who.int $/ \mathrm{malaria} / \mathrm{mpac} / \mathrm{sep} 2012 /$ primaquine_single dose_pf_erg_meeting_report_aug2012.pdf. 